\title{
I.В. Дудка \\ ДИСФУНКЦІЯ ЕНДОТЕЛІЮ ПРИ ШЛУНКОВО-СТРАВОХІДНОМУ РЕФЛЮКСІ У ХВОРИХ НА ХРОНІЧНЕ ОБСТРУКТИВНЕ ЗАХВОРЮВАННЯ ЛЕГЕНЬ
}

Вищий державний навчальний заклад України «Буковинський державний медичний університет», м. Чернівці

Резюме. У статті викладені результати дослідження функціонального стану ендотелію за умов поєднаного перебігу гастроезофагеальної рефлюксної хвороби (ГЕРХ) та хронічного обструктивного захворювання легень (ХОЗЛ). Встановлено, що загострення хронічного обструктивного захворювання легень супроводжується активацією індуцибельної NO-синтази та істотною гіперпродукцією монооксиду нітрогену, що $є$ передумовою розвитку шлунково-стравохідного рефлюксу. Підсилення NO-залежної релаксації нижнього сфінкте-

Вступ. Останнім часом зросла кількість досліджень, присвячених взаємозумовленості розвитку гастроезофагеальної рефлюксної хвороби (ГЕРХ) та загострень хронічного обструктивного захворювання легень (ХОЗЛ) $[1,10]$. У низці ретроспективних досліджень $[4,7]$ встановлено вірогідний ризик розвитку ХОЗЛ у хворих на ГЕРХ (67 \%) та статистично вірогідну асоціацію між загостренням ГЕРХ і загостренням ХОЗЛ. Водночас частим супровідним захворюванням, яке може істотно впливати на перебіг та прогресування ГЕРХ, є ХОЗЛ. Згідно з даними літератури, у 6080 \% хворих на бронхіальну астму та ХОЗЛ виявляють ГЕРХ [1, 9, 13].

Гастроезофагеальна рефлюксна хвороба - це хронічне рецидивне захворювання, зумовлене порушенням моторно-евакуаторної функції гастроезофагеальної зони із спонтанним, або таким, що регулярно повторюється, закидом у стравохід шлункового або дуоденального вмісту, та розвитком характерних клінічних симптомів, і призводить до пошкодження слизової оболонки дистального відділу стравоходу [1]. Провідним патогенетичним механізмом, який лежить в основі ГЕРХ, є порушення функції нижнього стравохідного сфінктера (НСC) - непосмугованого м'яза дистального відділу стравоходу, який має специфічну автономну моторну діяльність, власну іннервацію, кровопостачання. Ці особливості дозволяють виділити НСС як відособлене морфофункціональне утворення. Розслаблення НСС стимулюється блукаючим нервом через прегангліонарні холінергічні, постгангліонарні нехолінергічні та неадренергічні нервові волокна. Симпатична імпульсація посилює тонус НСС. Крім того, на міогенні властивості непосмугованих м'язів НСС впливають різні гуморальні фактори: гастрин, мотилін, гістамін, бомбезин, вазопресин, простагландин (ПГ)- $\mathrm{F}_{2 \mathrm{a}}, \alpha$-адреноміметики, $\beta$ адреноблокатори, які підвищують тонус НCC, а секретин, глюкагон, холецистокінін, нейротензин, шлунковий гальмівний поліпептид, прогес- ра стравоходу у хворих на хронічне обструктивне захворювання легень, разом із встановленим підсиленням агрегаційних властивостей крові, активацією факторів коагуляційного гемостазу та гальмуванням фібринолізу, $\epsilon$ важливими ланками потенціювання розвитку ендоскопічно позитивної ГЕРХ.

Ключові слова: гастроезофагеальна рефлюксна хвороба, хронічне обструктивне захворювання легень, ендотелій, гемостаз, фібриноліз.

терон, ПГ- $\mathrm{E}_{1}$, ПГ- $\mathrm{E}_{2}$, дофамін, $\beta$-адреноміметики, $\alpha$-адреноблокатори знижують тонус НСС [5]. У спокої м'язові волокна стравоходу перебувають у стані тонічної констрикції, при цьому в НСС створюється тиск від 10 до 30 мм рт. ст. (залежно від фази дихання). Під час ковтальних рухів тонус м'язів НСС знижується і після проходження їжі в шлунок просвіт нижньої частини стравоходу закривається. Даний механізм діє як фізіологічний бар'єр для запобігання закиду вмісту шлунка в стравохід. При ГЕРХ спостерігається гіпотонія або навіть атонія НСС, тиск рідко досягає 10 мм рт.ст. [4, 11]. За умов супровідного ХОЗЛ, шлунково-стравохідний рефлюкс (ШСР) може бути зумовлений зростанням кількості епізодів релаксації НСС (унаслідок кашлю, наявності подовженого видиху, гіпоксії); минучого зростання внутрішньочеревного тиску (внаслідок підвищеного опору на видиху внаслідок бронхіальної обструкції, під час виконання форсованого видиху при проведенні спірографії - стрес-рефлюкс); а також стабільної релаксації НСС (гіпотонія НСC) - вільний рефлюкс, що зумовлений фоновим холінергічним, адренергічним дисбалансом $[10,13]$, а також низкою ще невідомих досі патогенетичних механізмів.

Провідним нейромедіатором автономної системи стравоходу є монооксид нітрогену (NO). Він забезпечує регуляцію тонусу НСС, зокрема його релаксацію за гуанілатциклазним механізмом [3, 9]. Встановлено, що підвищений вміст нітратів та нітритів в їжі призводить до розслаблення НСС та змін конформаційної структури білків мембран клітин, у тому числі, епітелію стравоходу, і може сприяти розвитку ерозивного езофагіту і навіть виразок стравоходу. Крім того, у результаті метаболізму нітритів утворюється низка мутагенів, які можуть сприяти розвитку метаплазії (стравохід Барретта), так і розвитку новоутворень стравоходу [12]. Нещодавно було зроблено акцент на ролі нітрозитивного стресу в патогенезі загострень ХОЗЛ, підтвердженням 
якого $€$ зростання концентрації нітрозотіолів, пероксинітриту та інших метаболітів NO у повітpi, що видихається $[2,5]$. Підсилене утворення пероксинітриту внаслідок генерації NO активованою індуцибельною NO-синтазою (iNOS) альвеолярних макрофагагів $\epsilon$ важливим аспектом ушкоджувальної дії та посилення інтенсивності запального процесу при ХОЗЛ. На підтвердження цієї гіпотези також вказує зростання кількості нітротирозин-позитивних клітин (як результат збільшення формування нітриту та пероксинітриту) у мокротинні та бронхоальвеолярному лаважі у хворих на ХОЗЛ [14]. Цей фактор, ймовірно, може сприяти розвитку ГЕРХ та прогресуванню у хворих на ХОЗЛ. Водночас інтенсивність нітрозитивного стресу та активність iNOS, їх роль у патогенезі ГЕРХ, а також за умов асоціаії ГЕРХ та ХОЗЛ не вивчались.

Саме тому, пошук невідомих раніше механізмів розвитку та прогресування ГЕРХ у хворих на ХОЗЛ складає актуальність нашого дослідження.

Мета дослідження. Вивчити функціональний стан ендотелію, інтенсивність нітрозитивного стресу у хворих на ХОЗЛ із супровідною ГЕРХ.

Матеріал і методи. Обстежено 90 хворих на ХОЗЛ, у тому числі 30 пацієнтів із ендоскопічно позитивною неерозивною (ЕПН) ГЕРХ - 1-ша група, 30 - із ендоскопічно позитивною ерозивною (ЕПЕ) ГЕРХ - 2-га група та 30 хворих на ХОЗЛ без супровідної ГЕРХ - 3-тя група, віком від 37 до 63 років. Групу контролю склали 30 практично здорових осіб (ПЗО) відповідного віку. У всіх пацієнтів діагностовано ХОЗЛ ІІ стадії (GOLD 2 В). Діагноз ХОЗЛ встановлювали згідно 3 «Протоколом надання медичної допомоги хворим на хронічне обструктивне захворювання легень», затвердженим Наказом МО3 України за № 128 від 19.03.2007 «Про затвердження клінічних протоколів надання медичної допомоги за спеціальністю «Пульмонологія» та Наказом МОЗ України № 555 від 27.06.2013 «Про затвердження стандартизації медичної допомоги при ХОЗЛ». Згідно з рекомендаціями Монреальського консенсусу (2006) діагноз ГЕРХ встановлювали на підставі анамнестичних та клінічних (суб'єктивних) даних, підтверджених результатами рН-метричного та ендоскопічного (езофагогастродуоденофіброскопічного) дослідження.

Наявність ендотеліальної дисфункції (ЕД) оцінювали за вмістом у крові стабільних метаболітів монооксиду нітрогену - нітритів та нітратів (з реактивом Гріса), активністю iNOS (DRG) методом імуноферментного аналізу. Також вивчали антиадгезивну, антиагрегатну, антикоагулянтну та фібринолітичну активність ендотелію. Потенційну активність плазміногену (ПАП), вміст антитромбіну III (АТ III), сумарну фібринолітичну активність (СФА), неферментативну (НФА) та ферментативну фібринолітичну активність (ФФА) вивчали 3 використанням стандартних наборів реактивів фірми «Danush Ltd» (м. Львів). Агрегаційну активність тромбоцитів (АгАТ) (спонтанну та індуковану АДФ (у кінцевій концентрації 1,0х10 $10^{-6}$ моль/л) АгАТ) вивчали на аналізаторі агрегації тромбоцитів АР 2110 (ООО «СОЛАР-Україна», м.Харків) турбідиметричним методом.

Статистичну обробку результатів досліджень проводили із використанням параметричних та непараметричних методів варіаційної статистики. Статистична обробка отриманих результатів проводилась за допомогою ліцензійного пакета програм Statistica 6.0. Залежно від розміру вибірок та розподілу показників використовувалися параметричні (t-критерій Стьюдента) та непараметричні (U-критерій Манна-Уїтні) статистичні методи. Для оцінки взаємозв'язків між показниками, що вивчалися, використовувався кореляційний аналіз 3 обчисленням коефіцієнтів рангової кореляції за методом Спірмена (r). Статистичні дані представлені у вигляді середнє значення \pm стандартне відхилення $(\mathrm{M} \pm \mathrm{SD})$. Достовірною вважалась відмінність при значеннях $\mathrm{p}<0,05[6,8]$.

Результати дослідження та їх обговорення. У 97,8 \% обстежених хворих на ХОЗЛ встановлено наявність ЕД за істотним зростанням вмісту NO у крові порівняно 3 показником у ПЗО $(\mathrm{p}<0,05)$. Причому, як вказують дані, викладені в таблиці, у пацієнтів з поєднаним перебігом ХОЗЛ та ГЕРХ спостерігалося істотніше зростання вмісту NO у крові (у межах 70-90 \%), ніж у пацієнтів 3 ізольованим перебігом ХОЗЛ (на $42 \%$ ) $(\mathrm{p}<0,05)$.

Також встановлено, що інтенсивність нітрозитивного стресу зростала за мірою поглиблення запального процесу слизової оболонки стравоходу (COC). Так, у хворих на ХОЗЛ із супровідною ЕПН ГЕРХ вміст NO у крові перевищив показник у пацієнтів 3 ізольованим перебігом ХОЗЛ на $19,9 \%(\mathrm{p}<0,05)$, а у хворих на ХОЗЛ із супровідною ЕПЕ ГЕРХ - відповідно на 34,2 \% $(\mathrm{p}<0,05)$. Патологічна гіперпродукція NO ендотелієм легеневих судин, що сприяла розвитку нітрозитивного стресу, атонічній релаксації НСС та пошкодженню СОС у хворих на ХОЗЛ, ймовірно, виникла внаслідок індукції запальним процесом iNOS. Згідно $з$ отриманими даними (табл.), активність iNOS у хворих на ХОЗЛ була істотно підвищена і зберігала вищезгадану закономірність: у хворих 3-ї групи перевищувала показник у ПЗО у 17,7 раза $(\mathrm{p}<0,05), 1-і ̈$ групи - у 20,8 раза $(\mathrm{p}<0,05), 2-1$ групи - у 23,1 раза $(\mathrm{p}<0,05)$. Таким чином, саме через патологічну індукцію активності iNOS y хворих на ХОЗЛ виникає недостатність НСС та зростає потужність впливу факторів агресії (соляної кислоти, пепсину рефлюксату та зростання інтенсивності нітрозитивного стресу) із формуванням та прогресуванням ГЕРХ на тлі ХОЗЛ.

Водночас встановлено істотне порушення антиагрегаційної функції ендотелію за вірогід- 
Таблиця

Показники функціонального стану ендотелію, факторів протизгортальної та фібринолітичної системи у хворих на хронічне обструктивне захворювання легень із супровідною гастроезофагеальною рефлюксною хворобою та без неї $(\mathrm{M} \pm \mathrm{m})$

\begin{tabular}{|c|c|c|c|c|}
\hline Показник & $\Pi 30, n=20$ & $\begin{array}{c}\text { ХОЗЛ } \\
\text { (група 3), } \\
\text { n=30 }\end{array}$ & $\begin{array}{c}\text { ХОЗЛ із ЕПН ГЕРХ } \\
\quad \text { (група 1), n=30 }\end{array}$ & $\begin{array}{l}\text { ХОЗЛ із ЕПЕ ГЕРХ } \\
\quad \text { (група 2), } \mathrm{n}=30\end{array}$ \\
\hline $\mathrm{NO}_{\mathrm{x}}$, ммоль/л & $16,57 \pm 1,475$ & $23,45 \pm 1,522^{*}$ & $28,13 \pm 1,121 * / * *$ & $34,47 \pm 1,165 * / * * / * * *$ \\
\hline iNOS, нмоль/хвхл & $0,11 \pm 0,020$ & $1,95 \pm 0,007 *$ & $2,29 \pm 0,019 * / * *$ & $2,54 \pm 0,017 * / * * / * * *$ \\
\hline ПАП, хв. & $18,3 \pm 0,26$ & $16,2 \pm 0,41^{*}$ & $15,7 \pm 0,38^{*}$ & $14,2 \pm 0,15 * / * * / * * *$ \\
\hline Антитромбін III, \% & $95,50 \pm 2,014$ & $76,10 \pm 7,387^{*}$ & $69,75 \pm 5,683 * / * *$ & $64,38 \pm 3,247 * / * *$ \\
\hline СФА, $\mathrm{E}_{440} /$ мл х год & $1,68 \pm 0,022$ & $1,47 \pm 0,041^{*}$ & $1,29 \pm 0,007 * / * *$ & $1,16 \pm 0,009 * / * * / * * *$ \\
\hline НФА, $\mathrm{E}_{440} /$ мл х год & $0,48 \pm 0,018$ & $0,66 \pm 0,040^{*}$ & $0,69 \pm 0,009^{*}$ & $0,76 \pm 0,007 * / * *$ \\
\hline ФФА, $\mathrm{E}_{440} /$ мл х год & $1,20 \pm 0,025$ & $0,81 \pm 0,007^{*}$ & $0,60 \pm 0,012 * / * *$ & $0,41 \pm 0,005 * / * * / * * *$ \\
\hline АгАТ спонтанна, $\%$ & $2,10 \pm 0,123$ & $5,32 \pm 0,146^{*}$ & $6,75 \pm 0,173 * / * *$ & $7,53 \pm 0,217 * / * * / * * *$ \\
\hline АгАТ індукована АДФ,\% & $21,32 \pm 1,451$ & $37,45 \pm 1,120^{*}$ & $43,83 \pm 1,356^{* / * *}$ & $51,45 \pm 1,120 * / * * / * * *$ \\
\hline
\end{tabular}

Примітка. * - різниця вірогідна порівняно з показником у практично здорових осіб (p<0,05); ** - різниця вірогідна порівняно з показником у хворих на ХОЗЛ без ГЕРХ $(\mathrm{p}<0,05)$; *** - різниця вірогідна порівняно 3 показником у хворих на ХОЗЛ із супровідною ЕПН ГЕРХ $(\mathrm{p}<0,05)$

ним зростанням показників спонтанної АгАТ $(\mathrm{p}<0,05)$ та індукованої АДФ агрегації тромбоцитів $(\mathrm{p}<0,05)$ у всіх хворих на ХОЗЛ. Слід зазначити, що ступінь гіперагрегації тромбоцитів у пацієнтів 2-ї та 1-ї груп спостереження вірогідно перевищував показники у пацієнтів 3-ї групи порівняння $(\mathrm{p}<0,05)$. Даний факт частково пояснює механізм розвитку ендоскопічно позитивної, у тому числі ерозивної, ГЕРХ у хворих на ХОЗЛ із точки зору порушення мікроциркуляції в СОС. Подальший аналіз отриманих даних підтверджує цю гіпотезу. Зокрема, у хворих на ХОЗЛ встановлено істотне зниження протизгортальної активності ендотелію - вірогідне зниження вмісту у крові AT III: у пацієнтів 3-ї групи на 20,3\% порівняно 3 П3О (p<0,05), 2-ї групи - на $27 \%(\mathrm{p}<0,05), 1-і$ групи - 32,6 \% $(\mathrm{p}<0,05)$; зниженням фібринолітичної активності ендотелію (за зниженням ПАП у межах $12-25 \%(\mathrm{p}<0,05)$, СФА - у межах $18-20 \%$ $(\mathrm{p}<0,05)$ та ФФА - у межах 32-35\%, $<<0,05$ ) (див. табл.). Проведені дослідження вказують на взаємозумовленість порушення функціонального стану ендотелію у хворих на ХОЗЛ, розвитком та прогресуванням ГЕРХ.

Генерація нейтрофілами під час загострення ХОЗЛ значної кількості активних форм кисню і нітрогену та гіперпродукція NO ендотелієм унаслідок активації iNOS iз прогресуючим ушкодженням ендотелію призводить до істотної ЕД, що супроводжується мозаїчними вазоспазмами та паретичною вазодилатацією судин малого кола кровообігу [10], істотними розладами плинності крові та підсилення процесів адгезії формених елементів до судинної стінки. Зазначені обставини, ймовірно, відіграють вирішальну патогенетичну роль у розвитку ерозивних уражень СОС у хворих на ХОЗЛ.

\section{Висновки}

1. Загострення хронічного обструктивного захворювання легень супроводжується активацією індуцибельної NO-синтази та істотною гіперпродукцією монооксиду нітрогену, що є передумовою розвитку шлунково-стравохідного рефлюксу.

2. Підсилення NO-залежної релаксації нижнього сфінктера стравоходу у хворих на хронічне обструктивне захворювання легень, разом із встановленим дисбалансом агрегаційних властивостей крові, системи факторів коагуляційного гемостазу та фібринолізу, є важливими ланками потенціювання розвитку ендоскопічно позитивної гастроезофагеальної рефлюксної хвороби.

Перспективою подальших досліджень $\epsilon$ вивчення застосування селективних інгібіторів iNOS у комплексній терапії ХОЗЛ для усунення клінічних симптомів ГЕРХ унаслідок відновлення тонусу нижнього стравохідного сфінктера (гальмування iNOS), підсилення мікроциркуляції у слизовій оболонці стравоходу.

\section{Література}

1. Бабак О. Я. Гастроэзофагеальная рефлюксная болезнь. От теории к практике / О.Я. Бабак // Сучас. гастроентерол. - 2014. - № 4 (78). - С. 38-44.

2. Барабой В.А. Окислительно-антиоксидантный гомеостаз в норме и патологии / В.А. Барабой, Д.А. Сутковой; под. ред. Ю.А. Зозули. - К.: Чернобыльинтеринформ, 1997. - $257 \mathrm{c}$.

3. Дьяков І.М. Донатори і стимулятори синтезу оксиду азоту / І.М. Дьяков, О.О. Губанова, А.А. Кривошип // Ліки. - 2002. - № 3-4. - С. 55-59.

4. Опарин А. Г. Влияние сопутствующей гастроэзофагеальной рефлюксной болезни на клиническое течение и функцию внешнего дыхания у больных хроническим обструктивным заболеванием легких / А.Г. Опарин, А.А. Опарин, А.В. Титкова // Гастроентерологія. 2013. - № 3 (49). - C. 46-49.

5. Осадчук М.А. Роль диффузной нейроэндокринной системы в патогенезе и исходе гастроэзофагеальной рефлюксной болезни / М.А. Осадчук, А.В. Калинин // 
Рос. ж. гастроэнтерол., гепатол., колопроктол. - 2007. - T. XVII, № 3. - C. 35-39.

6. Основы компьютерной биостатистики: анализ информации в биологии, медицине и фармации статистическим пакетом MedStat / [Лях Ю.Е., Гурьянов В.Г., Хоменко В.Н., Панченко О. А.]. - Донецк: Папакица E.K., 2006. -214 c.

7. Островський М. М. До питання поліморбідності та коморбідності у хворих на ХОЗЛ / М. М. Островський, П. Р. Герич // Укр. пульмонол. ж. - 2011. - № 4. C. $19-24$.

8. Пилипенко М.I. Лекції з математичної статистики для лікарів / М.І. Пилипенко, С.Б. Радзішевська, В.Г. Книгавко. - Харків, 2001. -88 с.

9. Титкова А.В. Клинико-функциональные и иммуновоспалительные особенности сочетанного течения хронического обструктивного заболевания легких и гастроэзофагеальной рефлюксной болезни и их коррекция / А.В. Титкова // Мед. сьогодні і завтра. - 2013. - № 1 (58). - C. 81-85.

10. Шаверская Э.Ш. Клинико-патогенетическая характеристика течения гастроэзофагеальной рефлюксной болезни у больных хронической обструктивной болез- нью легких: автореф. дис. на соискание учен. степени канд. мед. наук: спец. 14.01.04 «Внутренние болезни» / Э.Ш. Шаверская. - Ижевск, 2013. - 25 с.

11. Шкарівський Ю.Л. Динаміка показників стану дихальних м'язів та функції зовнішнього дихання у хворих із хронічним обструктивним захворюванням легень у поєднанні з гастроезофагеальною рефлюксною хворобою на тлі антирефлюксної терапії лансопразолом / Ю.Л. Шкарівський, М.А. Станіславчук // Сучас. гастроентерол. - 2014. - № 5 (79). - С. 49-55.

12. Dedon P.C. Reactive nitrogen species in the chemical biology of inflammation / Dedon P.C., Tannenbaum S.R. // Arch. Biochem. Biophys. - 2004. - Vol. 423, № 1. - P. 12-22.

13. Liang Bin-Miao. Association of gastroesophageal reflux disease symptoms with stable chronic obstructive pulmonary disease / Bin-Miao Liang, Yu-Lin Feng // Lung. 2012. - Vol. 190, № 3. - P. 277-282.

14. Markers of inflammation and oxidative stress in exacerbated chronic obstructive pulmonary disease patients / W.B. Gerritsen, J. Asin, P. Zanen [et al.] // Respir. Med. - 2005. - Vol. 99, № 1. - P. 84-90.

\title{
ДИСФУНКЦИЯ ЭНДОТЕЛИЯ ПРИ ЖЕЛУДОЧНО-ПИЩЕВОДНОМ РЕФЛЮКСЕ У БОЛЬНЫХ ХРОНИЧЕСКИМ ОБСТРУКТИВНЫМ ЗАБОЛЕВАНИЕМ ЛЕГКИХ
}

\author{
И.В. Дудка
}

Резюме. В статье изложены результаты исследования функционального состояния эндотелия в условиях сочетанного течения гастроэзофагеальной рефлюксной болезни (ГЭРБ) и хронического обструктивного заболевания легких (ХОБЛ). Установлено, что обострение хронического обструктивного заболевания легких сопровождается активизацией индуцибельной NO-синтазы и существенной гиперпродукцией монооксида азота, что является предпосылкой развития желудочно-пищеводного рефлюкса. Усиление NO-зависимой релаксации нижнего сфинктера пищевода у больных хроническим обструктивным заболеванием легких, вместе с установленным усилением агрегационных свойств крови, активацией факторов коагуляционного гемостаза и торможением фибринолиза, являются важными звеньями потенцирования развития эндоскопически позитивной ГЭРБ.

Ключевые слова: гастроэзофагеальная рефлюксная болезнь, хроническое обструктивное заболевание легких, эндотелий, гемостаз, фибринолиз.

\section{ENDOTHELIAL DYSFUNCTION IN GASTROESOPHAGEAL REFLUX IN PATIENTS WITH CHRONIC OBSTRUCTIVE PULMONARY DISEASE}

\section{I.V. Dudka}

Abstract. The paper presents the findings of an investigation of the endothelial functional state under conditions of a combined course of gastroesophageal reflux disease (GERD) and chronic obstructive pulmonary disease (COPD). It was found that exacerbation of chronic obstructive pulmonary disease is accompanied by the activation of induced NO-synthase and considerable excessive production of nitrogen monoxide which is a precondition of gastroesophageal reflux development. Intensification of NO-dependent relaxation of the inferior esophageal sphincter in patients with chronic obstructive pulmonary disease together with the established intensification of aggregative blood properties, activation of the factors of coagulation hemostasis and inhibition of fibrinolysis, are important potentiation links promoting the development of endoscopic positive GERD. nolysis.

Key words: gastroesophageal reflux disease, chronic obstructive pulmonary disease, endothelium, hemostasis, fibri-

Higher State Educational Institution of Ukraine «Bukovinian State Medical University»,(Chernivtsi) 